\title{
Camus as Girard's Pharmakos: The Trial(s) of Mimetic Criticism
}

\author{
Eric Touya de Marenne \\ Adelphi University
}

II

n Deceit, Desire and the Novel, René Girard ascertained that a form of lie (or deceit) concealed the dynamic of violence in fiction. Pointing to the romantic illusion that dissimulated the heteronomy of desire, Girard challenged the logic of Camus' early works, arguing that the schemes of his first novels differed from later ones. The transition from L'Etranger to La Chute illustrated one of these transformations. Camus put forth a "lie", the philosopher argued, when he portrayed Meursault as victim of society. "Wicked hero" par excellence, the protagonist was in reality the author's scapegoat, Girard claimed, his mimetic rival. Thus, Camus was in truth responsible for the crime committed by his character: "Meursault est un personnage de fiction, et, en dernière analyse, c'est l'auteur lui-même qui est responsable de son crime."

By way of L'Etranger's main character, Meursault, Camus was able to hide the heteronomy of his own desire. This pretense, according to Girard, allowed violence to be disseminated in his work. It perpetuated the sacrificial system of mimetic desire dissimulated in the underground of consciousness. As he became aware of this concealed dynamic, Camus put an end to the "romantic illusions". This change occurred most notably in La Chute in which the novelist experienced "an existential downfall": "Ce qui s'effondre, c'est bien cette image flatteuse de lui-même que l'écrivain luttait pour situer et pour perpétuer." (CS, p. 116) [What collapses is this flattering image of himself that the author was attempting to perpetuate. $]^{2}$

1 Girard, René. Critique dans un souterrain (Lausanne: Editions L'Âge d'Homme, 1976), p. 125. The subsequent references from this book will be given in the text as "CS".

2 The translations of Girard's Critique dans un souterrain are mine. 
In L'Etranger, Girard contented, Camus perpetuated "scapegoat mechanisms" by justifying the hero's "criminal" act. Whereas the plot rested on the author's conviction of Meursault's innocence and on the hostility of the judges against him, Clamence confessed in La Chute that he and his clients were not as innocents as he had assumed. Through this "necessary conversion", Clamence implicitly recognized his share of responsibility in perpetuating the principles of mimetic desire and the dynamic of violence.

In spite of its originality, it is my contention that Girard's interpretation of Camus' novels revealed significant shortcomings. My aim, in this context, is not to cast doubts on the validity of Girard's overall philosophy but to question his strategies when he seeks to demonstrate the relevance of his thinking in the field of literary criticism. If one wished to be Camus' advocate, one could argue in effect that Girard's study failed to fully consider the author of L'Etranger's intentions. The critic's hypothesis and "systematic" analyses downplayed the novelist's cogito. It is worth noting that among other twentieth century scholars, Derrida similarly rejected the author's consciousness, contending that, in the end, a text constituted a continuity of contradictory and irreconcilable meaning, and that all reading necessarily presented a partial "misreading". From this angle, both psychoanalysis and post-structuralism adhered to the improbability of ascertaining an origin to consciousness, claiming that presence was illusory and unverifiable. Girard's lack of consideration for the author's intentions, and specifically Camus' aims as an existential writer, allowed the critic to recreate in his own terms the universe of the author. In an attempt to justify his hypothesis of mimetic desire and scapegoat theories, Girard transformed the religious, philosophical and ethical implications of Camus' novels.

In fairness to Girard, I have always found L'Etranger's scenario problematic. In his denying of the author's intention, however, Girard was not entirely innocent, even though in a very different way than Derrida. The former left no doubt as to the truth of his interpretation whose justification went in his views beyond any author's aim or intention. A rapprochement could however be made between the two critics in the context of mimetic criticism: Derrida's "deconstructive critique of metaphysics, logo-centrism...essentialism and the like, corresponds, in its structure and dynamics, to Girard's critique of sacrificial practices." 3

3 McKenna, Andrew. Violence and Différance (Carbondale: Southern Illinois University Press, 1992), pp. 12. The references to this work appear thereafter in the text under "VD". 
Derrida and Girard could therefore explicate each other, and "deconstruction [be reduced] to anthropological terms", even though the differences between the two critics should not be undermined: Derrida "means something very different by literature - rien for Derrida, real knowledge for Girard." (VD, p. 23) Girards source in "scriptural rehabilitation of the victim in Judeo-Christian tradition" contrasts with Derrida's critique of logo-centrism, and with the "playfulness [that] defies the possibility of anchoring any discourse." (VD, p. 23)

In spite of such oppositions: "theory of violence" versus "violence of theory", "agency of desire" versus "agency of the signifier", a "deconstruction of the difference between Derrida and Girard" could be attempted. Notwithstanding the "difference between a discourse concerned with signifiers and one concerned with victims, there is a formal or structural resemblance in the process of expulsion and mystification, analyzed by these two writers." (VD, p. 27) Derrida uncovered in "Plato's Pharmacy" "a mechanism of exclusion.... logic of sacrifice (as articulated by Girard)." Underlining the analogy between the expulsion of the pharmakon, as writing, and of the pharmakos, as the scapegoat that purifies the community, "the fate of the signifier in Derrida's reading is the same as that of the victim in Girard's analysis." (VD, p. 28)

According to this view, Girard and Derrida put forth a similar logic of sacrifice. And it is important to point out that Girard himself recognized these parallels, and through them, underlined the absolute dimension of mimetic desire. Taking the author of Des choses cachées depuis la fondation $d u$ monde at his word when he underlined the universality of the mimetic principles, I would contend that his investigation on Camus' L'Etranger failed to acknowledge the possibility that these given systems of beliefs could have been as determining factors in his analysis as they, in his views, had been in fiction. This lacuna illustrated one of the most significant shortcomings of Girard's literary analysis. Investigating the critic's inquiry,

4 In Plato's myth of Theuth, writing is portrayed as a dangerous drug offered to $\mathrm{Ra}$, the father of memory. The gift is rejected for impeding memory, for usurping its active functioning. By reading this, he says, men would cease to exercise memory because they rely on that which is written calling things to remembrance no longer from within themselves, but by means of external marks. Writing is invented as a supplement to speech, to presence of mind, to the origin as logos and logos as origin, and it is expelled for threatening to supplant it altogether. Plato labels it a pharmakon, a remedy-poison. (VD, p. 28) 
one can examine the extent to which his interpretation fell short of taking into account Camus' reality and how, through an ultimate expulsion of the author's intentions, Girard designated the novelist as the scapegoat, the pharmakos, in his criticism.

Was Camus, in L'Etranger, responsible for the crime of Meursault, as Girard alleged? The novelist and the critic merit further discussion based on this hypothesis alone. By undermining the author's consciousness, Girard accomplished what he claimed Camus had done with Meursault: the dissimulation of violence and annihilation of one's truth. If we lift the veil of analysis and reach the heart of both the novelist and the critic's reality, we can see how Girard's interpretations do not take into account Camus' sensibility and intellectual background and how the belief system of his hero fundamentally differed from the critic's. Girard's characterization of "good" and "bad" heroes is problematic in that respect. Were his condemnations of Meursault and vindications, of Clamence justified? The former was a victim, at least in Camus' eyes. This discrepancy shows the extent to which the critic and novelist's approach and understanding of the human experience in fiction and/or reality varied from one another. And the dissimilarity of their understanding was in a large part determined by their knowledge, or lack there of, of the mechanism of mimetic desire at play in human relation.

Girard's critique of sacrificial practice paralleled as we have seen in many respects Derrida's deconstructive practice of the signifier. In his attempt to rehabilitate the victim, Girard displaced Camus from being author, to becoming scapegoat. From a moral and existential perspective, the novelist sought like Girard to find answers to universal inquiries. He looked beyond given ideologies as he searched for a unifying system of human thought and behavior. The notion of "mimetic desire", however, did not represent for him a critical path for understanding human reality. He did not perceive from the same angle the arbitrary nature of victimization nor could he have accepted or rejected Girard's concept of scapegoat mechanism that enabled society to rid itself of its own violence.

Considering these dissimilarities of perspectives, Girard's unified scheme of thought would have constituted, for the author of L'Etranger, more a weakness than strength. The relation the critic established between violence and the sacred was founded in religion. It was from this perspective that literature took over the function of ritual to reveal the truth of humanity. Camus' novels uncovered, for Girard, mediated desires that were rooted in the violent origin of the sacred and the critic's theories on the foundation of the world sought to achieve a scriptural rehabilitation of

\section{LittéRéalité}


the victim in the Judeo-Christian tradition. Camus, on the other hand, condemned the cruelty of a presumed divinity that, in his views, had allowed the first murder of humanity: Abel's sacrifice and he accused the absurdity of the confrontation between a "miserable humanity" and an "implacable God", not hesitating to define Christianity as a "doctrine of injustice."

How could God have abandoned his Son on the cross? It is particularly revealing that Camus referred to Meursault as "le seul Christ que nous méritions" [the only Christ we ought to have]. Both Meursault and Christ were in his views persecuted. Both were the "strangers" and "scapegoats" of society. Neither could the identity of the victim nor the outcome and meaning of the sacrifice have thus been more contradictory from one author to the other. For Girard, the Passion put an end to the hidden system of "collective murder" in human society. Christ's death represented the first step outside the sacrificial system. Contrary to Camus' atheism that allowed scapegoat mechanisms to be perpetuated, the meaning of the sacrifice could only be revealed and explained for the critic through the Christian credo. It had to be redefined on the basis of God's own sacrifice. The suffering and death of the Christ originated from the inability of the world to receive the Son's commands and actions toward non-violence. ${ }^{6}$

A significant gap therefore separated the philosopher's hypothesis from the novelist's state of mind. In this respect, Camus' intellect and sensibility explained Meursault's psychological output. The protagonist of L'Etranger rejected all forms of Christian morality. Demonstrating the hero's passivity and indifference, Camus portrayed an assassin in spite of himself, exiled from the world into his own existence. Assuming that Meursault'a act had been premeditated, the judges were attempting to find a motivation and give a reason for his crime. Was he innocent? Was he a victim? Contrary to Girard's conception of victimization, the author wished to challenge the readers' judgment by showing the uncertainty of the answer. Meursault's alienation illustrated for some the unfolding of the human drama in a world without God. From nihilism emerged a terrifying logic. For others, his attitude expressed the emancipation from the traditionally dualistic (good versus evil) vision of the world. As expected, Meursault's image as "good criminal" was, for Girard, unacceptable: "Comment un homme peut-il commettre un crime et ne pas être responsable?" [How can a man

5 Fitch, Brian. Camus et la religion (Paris: Lettres Minard, 1982), pp. 14, 16.

6 Girard, René. Des choses cachées depuis la fondation du monde (Paris: Librairie Grasset, 1978). 
commit a crime and not be responsible?], he questioned (CS, p. 118). Was his act involuntary? To adopt the theory of the accident minimized his culpability.

Camus needed an "innocent murderer", Girard contended. The idea upon which rested his novel was thus improbable. It contradicted the exigencies of "realism". Meursault had committed a reprehensible act, yet Camus maintained his innocence. In light of his protagonist's indifference, the novelist pointed to the injustice of the judges. The two positions appeared irreconcilable. Camus was blind; he did not measure or refuse to accept the consequences and magnitude of his misunderstanding. According to Girard, the "trial of an innocent" fitted the archetype of a writer and man of exception victimized by society whom Camus identified with. For the latter, Meursault had only committed an act of intellectual despair that had resulted from arbitrary circumstances. Whereas the author justified the "carelessness" and the "indifference" of the hero, Girard contended that the novelist led the readers to believe that there was a crime but not a criminal, and that the murderer was in fact a victim. Instead of condemning the transgression, the readers blamed the reprisal of society. Rather than rejecting the book, "[Ils] le couvrirent de louange... Le public, en somme, se révéla composé non de juges, comme l'auteur l'avait pensé, mais d'avocats généreux comme lui-même, de gens qui lui ressemblaient." [They congratulated him.... The public was composed not of judges, as the author had thought, but of generous lawyers like himself, of people who looked like him]. (CS, p. 139)

Such a commentary illustrated yet another expression of the critic's exclusion of the pharmakos. Girard's assertions about the readers were based on his displacement of the author's consciousness, on suppositions that transgressed the originality of his thought. In light of the differences that separated the critic's interpretations from the novelist's intentions, Girard's accusations of the author were questionable. Was he responsible for the crime of the protagonist? Girard asserted that Meursault was just a character of fiction and that, in the final analysis, it was Camus himself who was responsible for the crime of the hero. Camus was thus becoming the critic's scapegoat in spite of the fact that from an existential standpoint, the novelist had described a hero living on the fringe of society, exiled from the world, and foreign to any form of morality. He was committing his murder for no apparent reason. Without psychological introspection, Meursault was passive and indifferent. He was not master of his actions and as the judges unsuccessfully attempted to give a motivation for his crime, Camus wished to make clear that Meursault was an assassin in spite 
of himself. His murder rendered a perfect illustration of the conflict within the existential experience, a divorce between reality and its interpretation, "d'une part, le flux quotidien et amorphe de la réalité vécue, d'autre part, la recomposition édifiante de cette réalité par la raison humaine et le discours." Whereas justice considered that Meursault's act had been premeditated, Camus presented through the whole novel a rupture between nature and its elucidation, between essence and existence. The prosecutor sought to reconstruct the past of the murderer, to give meaning to his act. But the judicial discourse could not comprehend his motives.

For Camus, Meursault's reality had been submitted to tragic laws of necessity that went beyond human comprehension and the hero could not have escaped the forces of destiny. He was, for the novelist, the "victim" par excellence, not the scapegoat of the author but of the "hidden" gods. Taking into account the author's intentions would have changed the outcome of Girard's judgment. Was La Chute portraying Camus' existential downfall and "conversion"? In contrast with Meursault, Girard saw Clamence, the protagonist of La Chute, as a "good hero" whose confession, he thought, divulged the "necessary collapse" of L'Etranger's "romantic illusion". The more Clamence attempted to break the symmetry of the mimetic process, Girard contended, the more he was affirming it. This realization was not only Clamence's, but more importantly Camus' own, in such a way that the author acknowledged the shortcomings of his preceding plots: "Ce n'est pas un personnage de fiction qu'il a sous les yeux, ce sont ses oeuvres antérieures." (CS, p. 15) It was not a fictional character that he examined, but his previous works that affirmed the good conscience of their heroes, whose vision of reality $L a$ Chute now challenged. Clamence's self-criticism revealed a quasi spiritual conversion: "Las de la popularité dont il jouissait auprès des bien pensants de l'élite intellectuelle, [l'auteur] trouva une façon subtile de tourner en dérision son rôle de 'prophète'... La confession de Clamence, c'est celle au sens large de confession spirituelle et littéraire, de Camus." (CS, p. 117) Thus, the author now turned in derision his role of prophet, Girard suggested, and Clamence's confession was, in fact, Camus' own.

In this denying of the author's intention and beliefs, Girard defined Camus' presumed conversion in his own terms. The phenomena he described, was more determined by his overall argument than by the novelist's reality. Indeed, why should the author of L'Etranger, a nonbeliever, have cared to make this spiritual journey to accomplish a literary

7 Sartre, Jean-Paul. Situation I (Paris: Editions Gallimard, 1947), p. 152. 
"confession"? How could Clamence have been an allegorical representation of the author's downfall and conversion, and Meursault, Camus' ideal victim? Based on Girard's interpretation, La Chute shed a greater light on the "mauvaise foi", the hypocrisy of the author of L'Etranger. By way of a reversal of the logic of literary criticism, Camus seemed to follow Girard's footsteps in such a way that the analysis determined Clamence's path toward "redemption". Through the universal dimension of mimetic desire, Girard transcended fiction and imposed to it the logic of his own interpretation, making the author's real intentions ultimately irrelevant.

Having confessed his "sins", Clamence recognized that all the clients he defended were not as innocents as he had claimed and Girard assimilated this conversion into both the author and protagonist's change of heart: "Meursault-Clamence se croit d'abord victime d'une erreur judiciaire, mais se rend finalement compte que la sentence est juste, même si les juges pris individuellement, sont injustes, parce que le Moi ne peut offrir qu'une parodie grotesque de Justice." (CS, p. 142) In this mea culpa, Girard suggested, it is himself that Camus examined with a critical eye. The author of L'Etranger had been the mastermind behind the protagonist's crime and the readers who had previously admired the courage and the "innocence" of Meursault now could not fail, Girard contended, to see in La Chute Camus' "real chef d'oeuvre." Clamence's value system collapsed before our eyes. The hero failed to demonstrate that he was on the side of the "good victims".

One could legitimately ask whether this transformation Girard envisioned was really taking place or whether it resulted from an act of faith and/or desire. Two points should be made here. First, Girard's account of sacrificial practices in Camus' novels is as paradoxical as Derrida's deconstruction of consciousness. Girard legitimized in his critical work what he denounced in his theories, namely the expulsion of the scapegoat or pharmakos, in the context that we have defined, Camus himself. In the same fashion, Derrida's critiques of method and system of reading necessarily succumbed to the norms he criticized. Second, any text's interpretation that does not take into consideration an author's intention can be legitimate. The predicament with Girard's understanding of Camus, however, is that the philosopher does not acknowledge the approach he has taken, which is to ignore the author's purpose. By doing this, Girard

8 Girard demonstrated how Camus' "moral vision" had been transformed in $\mathrm{La}$ Chute. No element in the author's biography, however, indicates that Clamence's presumed conversion led to the "redemption" of the author. 
perpetuated the logic of the pharmakos' expulsion in his criticism, the very dynamic that in his views determined the discourse of Camus' fiction.

But it is arguably because of certain resemblances that Girard found interest in Camus before discarding, "excluding" from the novelist's works, what would impede the logic of the analyst's demonstration. The writings of La Peste, L'Exil et le Royaume and L'Homme révolté which in fact Girard did not cite, confirm this assertion. Even from an existential standpoint, the plague, like mimetic desire, is an evil that must be counted with. In that respect, the novelist shared with the critic, even though from a different angle, if not a Christian, surely a humanistic interpretation of history. Such a parallel allows us to further examine Camus' L'Etranger from a different perspective. Written in 1942 during the German occupation of France, the novel illustrated, through the role of the protagonist, an act of desperation, a killing that concealed in fact a great despair, and arguably, a form of suicide. From this viewpoint, Meursault's murder takes on another dimension and Camus' plot needs to be studied against the background of his relation with the foreign ("l'étranger") occupier. Its overwhelming yet ambiguous presence (let us remember the importance of the blinding sun at the time of the murder that gave the scene of the killing a surreal aura) influenced if not determined the outcome of the story.

In this respect, Camus' subtext also raised another important question: to what extent was it legitimate to kill a "foreign" occupier? Situated in this historical context, L'Etranger foresaw La Peste through its denunciation of the calamity of violence (a condemnation largely reflected in Girard's discourse), against which the novelist found no answer in religion. In fact, the indifference of Meursault contrasted greatly with Camus' real commitment in the Résistance. The protagonist was, in this sense, not the scapegoat but the alter ego/anti-thesis of the author, alter ego for pulling the trigger, and anti-thesis, in an existential context, for lacking the motives. From a different angle, if in La Peste, Tarrou/Rieux, asked in despair, like Camus, how and why one should/could be a saint without God, faced with the horror of the plague, Girard would have followed another path, perhaps the one of Paneloux.

In spite of these parallels and contrasts, one cannot deny that Camus' "moral" vision differed greatly from Girard's. It was vain, for the former, to believe in a system of higher principle that would justify evil and suffering. L'Exil et le Royaume, however, added with "L'Hôte" another dimension to the possible significance of mimetic desire. Daru was torn between his condemnation of the crime the Arab had committed and his compassion for the murderer. He let, at the end, his guest decide the fate of his destiny, 
to in turn become the victim of the villagers with whom he had lived. Camus' sensibility was once again revealed in this passage that exemplified the paradoxes and ambivalences he saw in the human experience, beyond what opposed, for the novelist, the "silence" of the world and Girard's "revelations".

As with Derrida's deconstruction of presence, Girard's interpretation of Camus was legitimate on its own terms, in the context of the critic's reality. It did not take into account the complexity of the author's thought and motives, however, the historical background from which the text had emerged. Camus' attempt to comprehend the mysteries of the world was confronted by its very irrationality, "le silence déraisonnable du monde." Differently, the Scriptures revealed to Girard the very truth in which Camus found no refuge. The author of La Peste questioned, in the absence of finitude, the justification for living. The novel, nevertheless, did not hide a "sacrificial practice", and, in spite of the author's own despair, it did not lead to irony but to an ascetic and active affirmation, not to a rejection of, but a new bond with the world. In contrast with the cult of the supreme will Nietzsche introduced with Zarathrousta, against also, and above all, Caligula's terrifying logic, L'Homme révolté constituted a supreme condemnation of violence. Girard, however, did not mention these very important texts that would have presented, in a very different light, Camus' intentions in L'Etranger and La Chute. Here, the thought of the philosopher and critic showed its limits. Girard's concept of mimetic desire and scapegoat theory missed an important point when it was applied to literary criticism: that all humans are potentially victims even when they face the reality of their lack of innocence. And in an ultimate turn around, Camus invites us to re-examine Girard's precepts of mimetic desire, and through this reassessment, question the legitimacy of literary criticism, when it seeks to perpetuate and justify its own discourse.

\section{Works cited}

Brian, Fitch. 1982. Camus et la religion. Paris: Editions Minard.

Camus, Albert. 1962-1965. Euvres complètes, 2 vol. Paris: Editions Gallimard.

Girard, René. 1976. Critique dans un souterrain. Lausanne: Editions L'Âge d'Homme.

1978. Des choses cachées depuis la fondation du monde. Paris: Librairie Grasset. 
1965. Deceit, Desire and the Novel. Baltimore: The Johns Hopkins University Press.

McKenna, Andrew. 1992. Violence and Différance. Carbondale: Southern Illinois University Press.

Sartre, Jean-Paul. 1947. Situation I. Paris: Editions Gallimard. 